\title{
Scour hole development in river beds with mixed sand-clay-peat stratigraphy
}

\author{
Y. Huismans, G. van Velzen, T.S.D. O’Mahoney, G.J.C.M Hoffmans, A.P. Wiersma \\ Deltares, Boussinesqweg 12629 HV Delft, the Netherlands
}

\begin{abstract}
River deltas are often characterized by a heterogeneous subsoil stratigraphy, composed of layers of sand, clay and peat. This has important consequences for the riverbed morphology and in particular the formation of scour holes. When the riverbed is composed of poorly erodible clay or peat, erosion processes are retarded. However, when thinner parts of clay or peat layers erode; underlying sand patches are incised and large scour holes may develop within in a short amount of time. The unpredictability and fast development makes these scour holes difficult to manage while stability of dikes and infrastructure may be at stake. In this paper we study the scour hole formation and development in heterogeneous subsoil. The Rhine-Meuse estuary forms the ideal system for this analysis as it has been intensively measured and contains about 100 scour holes. Based on nearly 60 years of river bed topography data and data on the subsurface lithography and hydrodynamics, we present a system analysis of scour hole formation in heterogeneous subsoil stratigraphy. In addition the detailed growth of a recently formed scour hole is studied and compared to scale model tests.
\end{abstract}

\section{INTRODUCTION}

Most of world's deltas are densely populated and contain high economic value. Safety against flooding is therefore of crucial importance. Scour holes in the riverbed increase the risk of riverbank instability (flow slides) and damage to structures like groynes, quays, bridge piers, and pipelines. Especially in areas with heterogeneous subsoil, like river deltas, sudden scour hole formation may occur. Due to the geological evolution in deltas, the lithology of the subsoil shows large variations in highly erodible sand and poorly erodible peat and clay layers (Berendsen and Stouthamer 2001; Cohen et al. 2012; Hijma 2009). The erosion is consequently not evenly distributed over the riverbed. Local incision of sand patches between areas with poorly erodible bed causes sudden scour hole development, ultimately leading to deep scour holes with steep slopes (Sloff et al. 2013; Huismans et al. 2015). This process is illustrated in Figure 1.1. Without detailed knowledge on the geology, these scour holes are unpredictable in formation and growth. In combination with their fast development and large depth, these scour holes are hard to manage. More knowledge on scour hole formation in heterogeneous subsoil is therefore required, while little research has been carried out so far.

Due to differences in local geology, hydrodynamics and local geometry, every scour hole develops differently. To understand the various influences on scour hole formation, it is consequently important to study a large set of scour holes. The Dutch RhineMeuse estuary forms the ideal system for this, as it contains a large number of scour holes and has an extensive set of geological, bathymetric and hydrodynamic data available.

\section{Bed level lowering due to erosion}
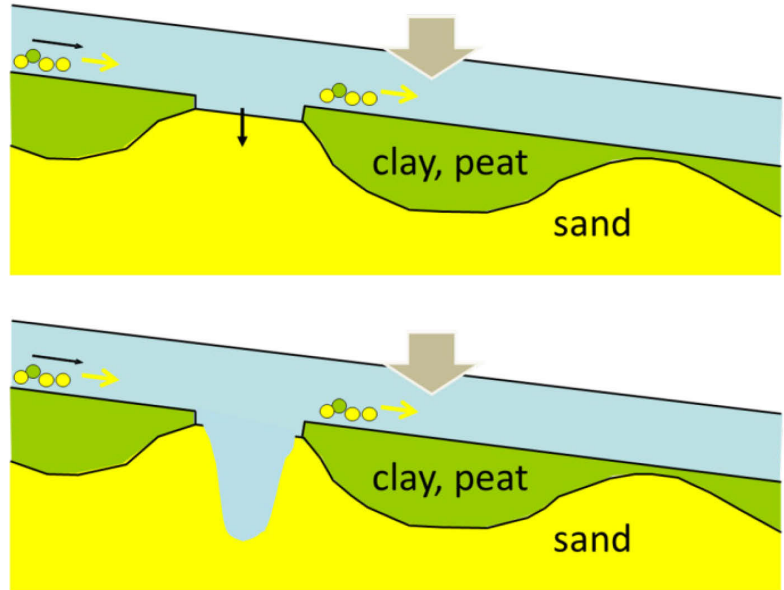

Figure 1.1 Principle of scour hole formation in heterogeneous subsoil (Sloff et al. 2013)

In this paper we study the scour hole formation in two steps. First we perform a general analysis of a large set of scour holes by categorizing them and by 
determining when they were formed. Based on this overview a link to geology and anthropogenic influences is made. To get a better understanding of the detailed growth a selection of scour holes was studied extensively by closely analysing the nearly 60 years of available single- and multibeam surveys, in combination with knowledge on the local hydrodynamics and geology.

In the following we will first give an introduction to the Rhine Meuse estuary, its main hydrodynamic and morphodynamic behaviour and subsoil composition. After a description of the data and methods the analysis of scour holes formation in heterogeneous subsoil stratigraphy will follow, including the comparison to scale model tests.

\section{THE RHINE-MEUSE ESTUARY}

An overview of the Rhine-Meuse estuary is given in Figure 1.2. It shows how the Rhine and Meuse confluence and discharge into sea via a complex system of river branches. Except for the southern branches, most branches have a negative bed level trend. In the northern part this is attributed to dredging, in the connecting branches this is attributed to erosion, related to closure of the Haringvliet in 1970. Before closure, the Rhine Meuse estuary had two open connections to sea: the Nieuwe Waterweg and the Haringvliet. The phase and amplitude of the tide between the northern and southern part were comparable, and therefore also the water levels. After building the Haringvlietdam the tide in the southern part diminished, resulting in much larger water level difference between north and south and much higher flow velocities in the connecting branches (Sloff et al. 2013). These branches currently show erosion trends up to $6 \mathrm{~cm} /$ year and contain many deep scour holes, of which most are still developing in depth or extent (Huismans and van Duin 2016).

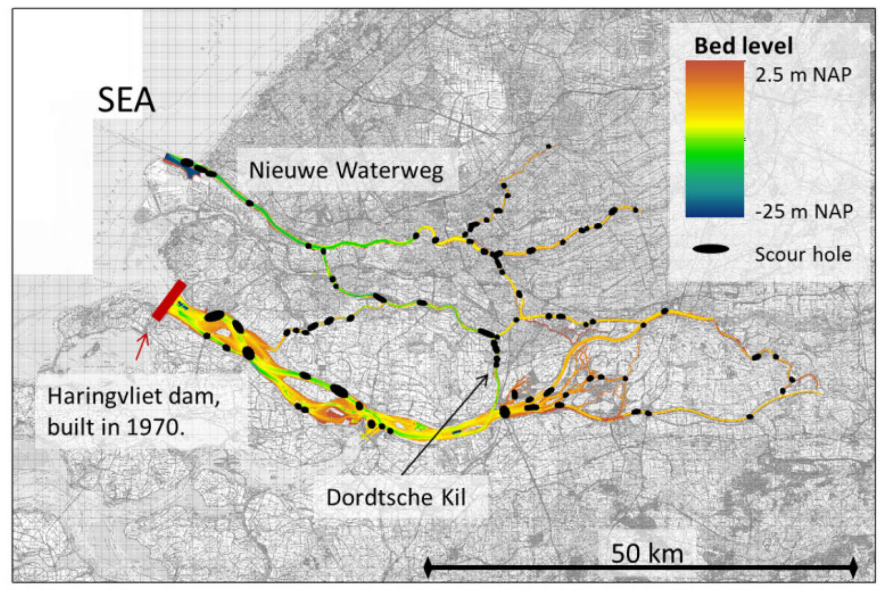

Figure 1.1 The Rhine Meuse estuary. The bed topography is given in color, the scour hole locations are indicated in black.
To illustrate the heterogeneity in subsoil composition the geology below the river bed is shown in Figure 3.1 for one of the connecting branches, the Dordtsche Kil River (Wiersma 2015). It shows how the peat, clay and sand layers from the Pleistocene and Holocene alternate. The sand patches interrupting these layers are channel belts of old river courses which cross the current river course. Because rivers deposit sand, these show up as sand patches. The depth and size relate to the age and width of the original river. In Figure 3.1 it is shown how deep scour holes have formed in these sandy channel belts. Scour holes may also form when the Pleistocene sand is locally incised, while the remainder of the river bed is composed of peat or clay, as illustrated in Figure 1.1.

\section{DATA AND METHODS}

As a first step in the analysis scour holes were identified based on the multibeam echosounder data of 2012 (5 m x $5 \mathrm{~m})$. This was done based on visual inspection of the data in GIS and resulted in approximately 100 scour hole locations as presented in Figure 1.2. For the further analysis focus was put to the most important branches, the Oude Maas, Nieuwe Maas, Noord, Dordtsche Kil, Spui and Amer. The 30 scour holes in these branches were divided into three categories:

A. Length shorter than $200 \mathrm{~m}$ and not located close to a structure.

B. Length longer than $200 \mathrm{~m}$, not located close to a structure.

C. Scour holes located nearby a structure (e.g. bridge piers, groynes, narrowing of the river), any length.

The idea behind this classification is that scour holes in category A and B have no clear cause and are probably related to the heterogeneity in the subsoil, as illustrated in Figure 1.1. Scour holes in category $\mathrm{C}$ will also form in a homogeneous sandy river bed. Though inhomogeneities in the subsoil will certainly influence their formation and shape, their prime cause is related to the presence of a structure. The distinction in length (A and B) was made with the idea that younger scour holes are generally smaller. Based on the yearly single-beam echosounder (1967 - 2005) and multi-beam echosounder (2005 - present) the historic evolution of the classified scour holes was mapped. 


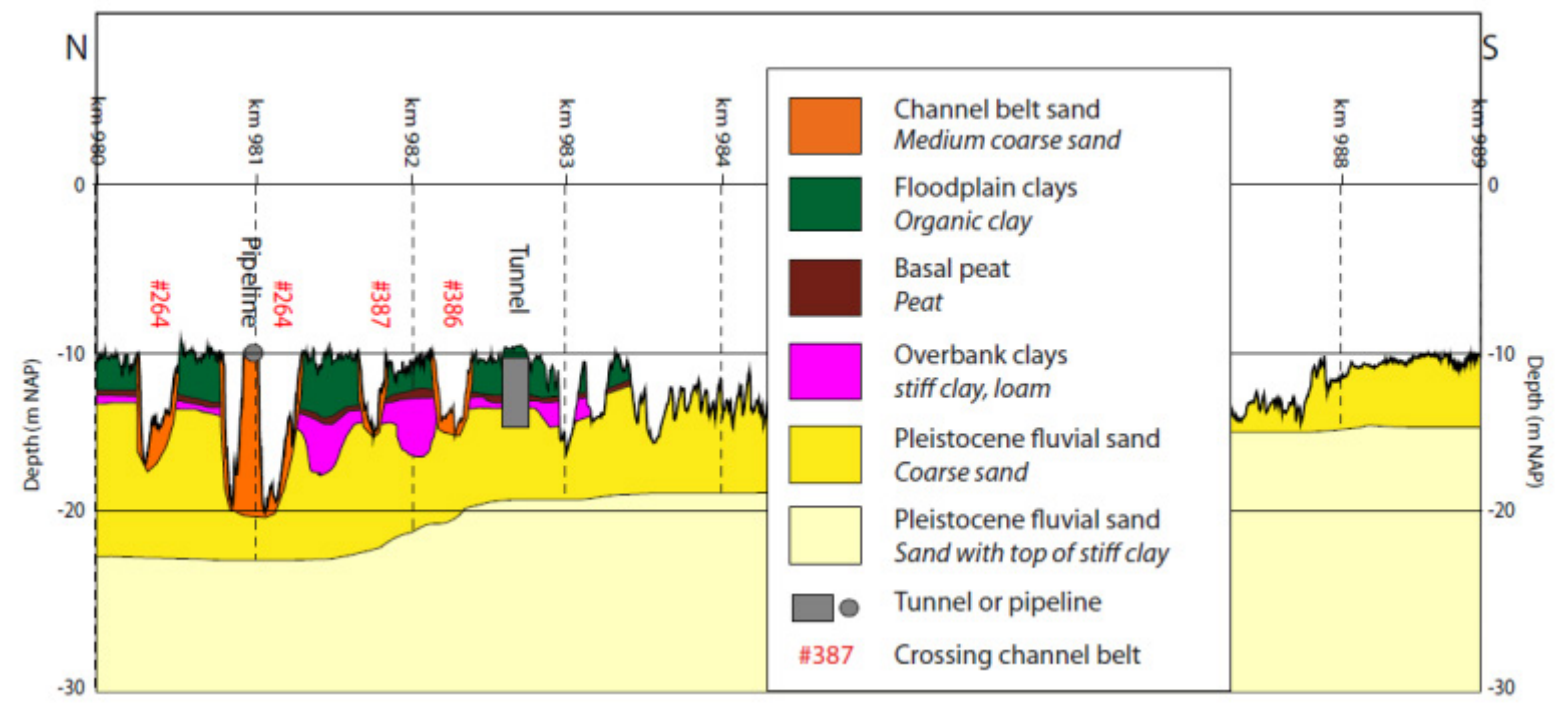

Figure 3.1 Subsurface lithology below the Dordtsche Kil river (Wiersma 2015). The current bed topography is imprinted on this longsection, with on its horizontal axis the river chainage value in kilometers $(\mathrm{km})$. The various layers have formed during different geological eras. Old river courses (in orange) have deposited sand. These rivers may have crossed the current river course as is the case in the Dordtsche Kil. Remaining channel belts show up as patches of sand in the clay and peat layers. Note that the location of all layers and channel belts are based on bore holes, river bathymetry and geological interpretations, as such there is a high uncertainty in their exact location.

In the second step a detailed analysis of six scour holes was carried out. With the bed topography data from $1970-2012$ the scour hole evolution was analyzed. For the period for which multibeam echosounder data is available $(2005$ - 2012) a detailed analysis of the growth in depth and extent and the slope evolution was made. Based on the historic scour hole evolution, the subsurface lithology and an estimation of the equilibrium depth, an outlook on the future scour hole evolution was made. An indication of the equilibrium depth was obtained with the following formulas (Hoffmans 2012):

$$
\begin{aligned}
& \frac{y_{m e}}{h}=\chi_{e}\left(\frac{U_{0}}{U_{c}}\right)^{2}-1 \text { for } U_{0}<U_{c} \\
& \frac{y_{m e}}{h}=\chi_{e}-1 \text { for } U_{c}<U_{0} \\
& \chi_{e}=\frac{1+6.3 r_{0}^{2}}{1-6.3 r_{0, m}^{2}}
\end{aligned}
$$

With the equilibrium depth of the scour hole, $y_{m e}$ $[\mathrm{m}]$, the waterdepth $h[\mathrm{~m}]$, the turbulence coefficient $\chi_{e}[-]$, the face velocity $U_{0}[\mathrm{~m} / \mathrm{s}]$, the critical velocity, $U_{c}[\mathrm{~m} / \mathrm{s}]$, the turbulence intensity upstream of the scour hole $r_{0}[-]$ and the turbulence intensity in the scour hole $r_{0, m}[-]$. Estimates for the face velocities were retrieved from a quasi 3D Delft3D model of the area (Ottevanger and van der Mark 2016; Huismans et al. 2015).

In the final step the detailed growth of a recently formed scour hole was compared to scale model experiments carried out by Zuylen and Sloff (2015).

\section{RESULTS AND DISCUSSION}

\subsection{Scour holes from 1967 to present}

In Figure 3.2 an overview of the date of origin of the scour holes in the main branches is given. For the scour holes older than 2005 the identification was based on the single-beam echosounder data. As these do not give full coverage of the river bed, the date of origin is only accurate to within a few years. Exact dates are therefore not presented here.

\section{Date of origin of RMM-scours}

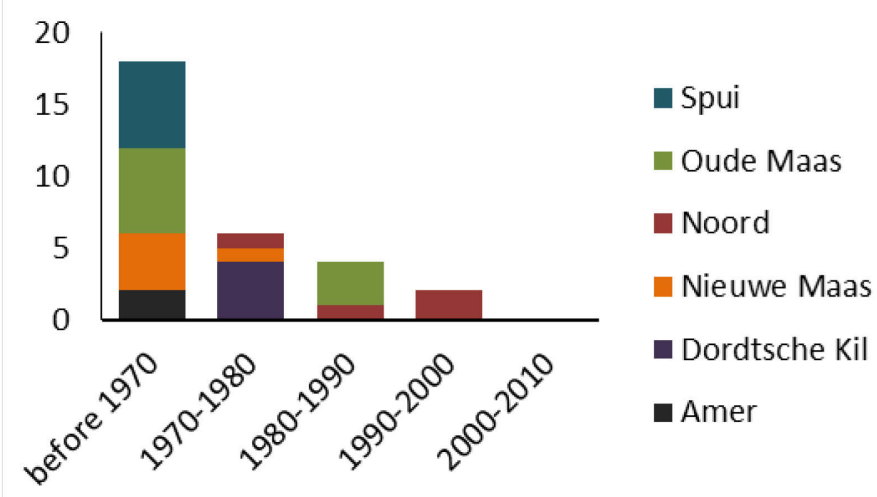

Figure 3.1 Date of origin as derived from inspection of the single- or multi-beam echolood measurements.

As mentioned in section 2, the flow velocities in the connecting branches have increased drastically with the closure of the Haringvliet in 1970. This has led to the assumption that the closure of the Haringvliet has been an important driver for the genesis of the scour holes. The bar plot in Figure 3.2 
however shows that most of the scour holes already existed before 1970. As erosion has increased, the scour holes most likely have undergone an increased growth after closure. This has not yet been researched.

In the period just after closure, six scour holes emerged, of which all were Dordtsche Kil scour holes. Their initiation is however most likely caused by reconstruction of the Dordtsche Kil during 19701984 instead of by the closure of the Haringvliet. Based on the short timespan in which they emerged and the subsurface lithology (see Figure 3.1), the protecting clay layer was probably removed when the river bed was deepened to $-8 \mathrm{~m}$ NAP (nowadays even $-10 \mathrm{~m} \mathrm{NAP}$ ), uncovering the sand bodies from the channels belts.

Categorization shows that the majority of the scour holes is not located nearby a structure and has no clear cause, see Figure 4.1. This stresses the relative importance of the other drivers for the formation of scour holes, like the subsurface lithology. Categorization furthermore shows that most of small scour holes (Category A, L < $200 \mathrm{~m}$ ) are actually decades old (not shown in the figure). This may be related to the geology. When the edges of the scour hole are made up from thick layers of peat or clay, further horizontal growth will be limited, confining the scour hole.

\section{Scour classification}

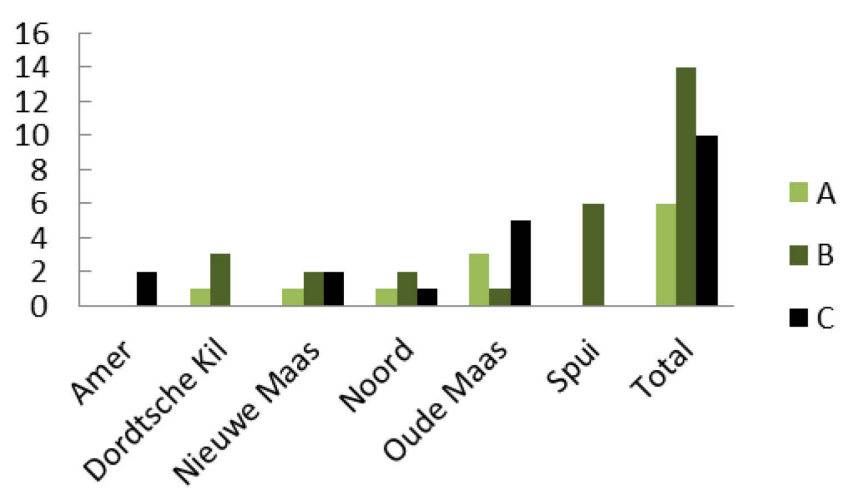

Figure 4.2 Scour hole classification into categories A, B and C (see method-section).

\subsection{Detailed analysis on scour evolution}

For six scour holes a more detailed analysis has been carried out. In this paper we present the full analysis for two scour holes, one in the Dordtsche Kil ("dkl_2") and one in the Noord ("nor 3"), followed by a more global discussion for the other scour holes.

The "dkl 2" scour hole is located in the northern part of the Dordtsche Kil. The local bed topography and surrounding subsurface lithology are shown in Figure 4.2 and Figure 3.1. "Dkl_2" is composed of two scour holes, separated by an elevation in the bed topography, under which a pipeline is located. Though the southern scour hole emerged earlier, the current depth of the northern scour hole is larger. Over the past few years, its depth increased from $16 \mathrm{~m}$ NAP to $20.5 \mathrm{~m}$ NAP, while its growth in extent has been limited to a few percent. As a consequence the slopes have increased over time. The limited growth in extent may be related to the geology. According to the subsurface lithology profile the scour hole has formed in an old channel belt and is surrounded by thick layers of clay. This hypothesis is supported by the presence of slopes of 1:2 to even 1:1 and the particularly shaped separation between the two scour holes. An alluvial bed would show smoother shapes and milder slopes.

Based on the recent developments, the depth of the scour hole is expected to increase and exceed its current value of $-20.5 \mathrm{~m}$ NAP. To estimate its future growth, the equilibrium depth was calculated with equations $(1.1-1.3)$, for which the following values were used: a face velocity of $0.8 \mathrm{~m} / \mathrm{s}$, a waterdepth of $10.5 \mathrm{~m}$, a turbulence intensity of 0.3 and 0.15 respectively inside and upstream of the scour hole, and critical flow velocities of $0.4 \mathrm{~m} / \mathrm{s}$ for sand with a grain size of $1 \mathrm{~mm}$ and $1.5 \mathrm{~m} / \mathrm{s}$ for clay (Hoffmans and Verheij 1997). This results in an equilibrium depth of -27 m NAP and suggests a further growth of over 6 meter. Based on its past development, this seems to be an overestimation. Because these formulas are highly sensitive to the input values on local flow conditions, for which only estimates were available, an overestimation is not unlikely. Moreover they do not account for variations in the geology. Judged on the subsurface lithology (Figure 3.1) the growth in depth will most likely be stopped by the clay layer at a depth of approximately -23 m NAP.

Based on the recent growth in extent and the presence of thick layers of clay one may expect limited future growth. Slopes are however getting steeper. Undermining and future failure of clay-layers can therefore not be excluded. As these scour holes are located nearby riverbanks, this poses a potential threat to the river bank stability. 


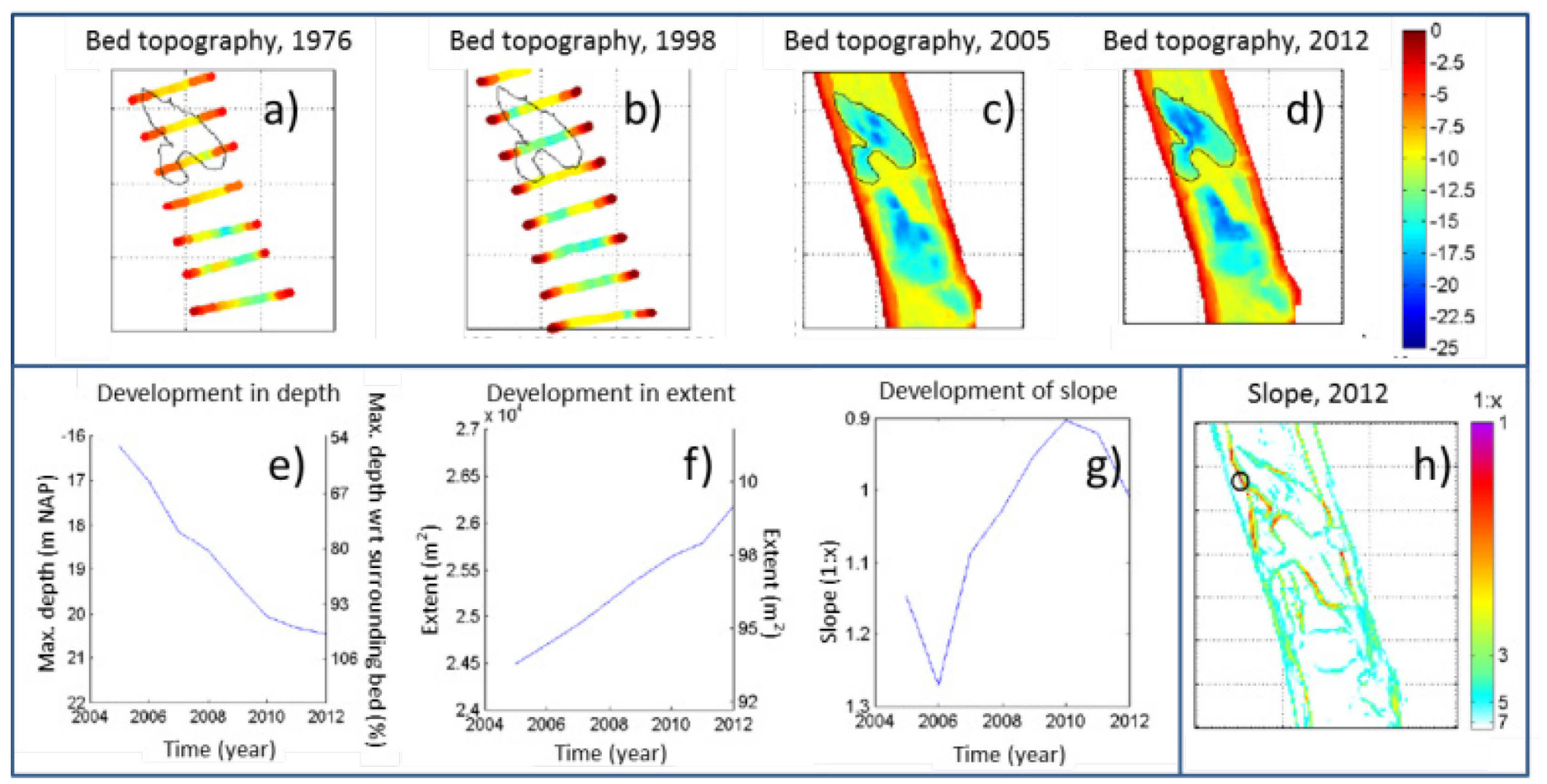

Figure 4.3. Top panel (a-d), evolution of the bed topography for scour hole "dkl_2". The contour in (a), (b) and (d) indicates the contour of the northern part of the scour hole in 2012, the contour in (c) is the contour in 2005. Bottom panel (e-h), recent development in depth, extent and slope, $(2005-2012)$ and in (h) the current slopes (2012).

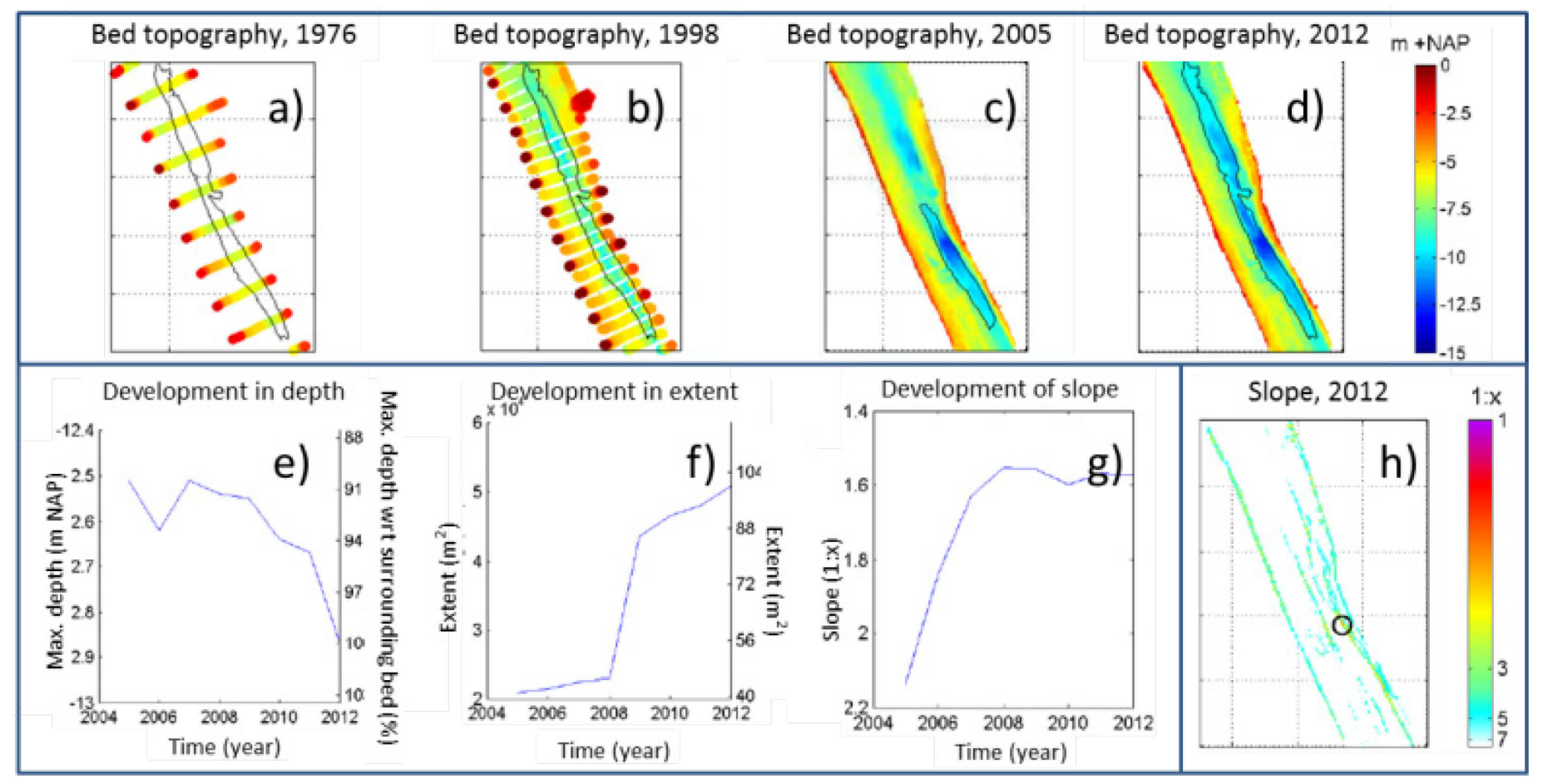

Figure 4.4 Top panel (a-d), evolution of the bed topography for scour hole "nor_3". The contour in (a), (b) and (d) indicates the contour of the northern part of the scour hole in 2012, the contour in (c) is the contour in 2005. Bottom panel (e-h), recent development in depth, extent and slope, $(2005$ - 2012) and in (h) the current slopes (2012).

The second scour hole which has been analyzed in depth is the "nor_3", which is an elongated scour hole located in the river Noord. Its evolution in bed topography and slope are shown in Figure 4.3. Because the river is relatively narrow at the location of nor_3, there is a local positive gradient in sediment transport accounting for the erosion. The very gradual development between 1976 and 1999 is related to the bed composition. Most of the river bed is located in layers of poorly erodible clay and peat, slowing down the erosion process. Between 1999 and 2005 the erosion accelerated. This may be caused by inci- 
sion of the Pleistocene sand, which is located at a level of -11 to $-14 \mathrm{~m}$ NAP, below the clay and peat layers. Up to 2005 the scour hole consists of smaller scour holes which merge together around 2009 to form a long trench. After 2009, an acceleration in growth in depth is shown, which may be related to the "attraction of flow", caused by the existence of the long trench.

The equilibrium depth has been calculated with equations (1.1 - 1.3), for which the following values were used: a face velocity of $1 \mathrm{~m} / \mathrm{s}$, a water depth of $6.5 \mathrm{~m}$, a turbulence intensity of 0.2 and 0.15 respectively inside and upstream of the scour hole, and critical flow velocities of $0.5 \mathrm{~m} / \mathrm{s}$ for the Pleistocene sand. This resulted in an equilibrium depth of $3 \mathrm{~m}$, i.e. $10 \mathrm{~m}$ NAP. Its current depth is $13 \mathrm{~m}$ NAP. The underestimation may be related to an underestimation of the face velocity, as the trench attracts flow and has presumably higher velocities than the width averaged values from the model. In addition, the formulas used do not account for the self-reinforcing effect of attraction of flow and deepening of the trench. Based on the history of the scour hole evolution and the geology, a further deepening is expected, possibly enhanced by the attraction of flow. Growth in extent may also be expected as the clay and peat layers covering the Pleistocene sand are expected to be thin at some of the scour hole edges. Based on the increase in steepness of some slopes, undermining may occur in the future. As these slopes are located only $40 \mathrm{~m}$ from the embankments, this may pose a potential threat to the stability.

From the six analyzed scour holes we can conclude that each develops in a different way. Some are stable, some show the strongest grow in depth, others show the strongest growth in extent. Differences in geology may largely account for the observed differences. Thick layers of clay on the edges limit growth in extent. This typically occurs for scour holes formed in channel belts, like for "dk1_2". Thinner clay or peat layers on the edges allow for growth in extent and even merging of scour holes. This typically happens when the Pleistocene sand is incised, like for "nor 3". When the river bed is composed of peat or clay, erosion processes are retarded. Incising sand layers will lead to sudden acceleration of the growth in depth. When scour holes are partially formed in clay or peat, steep slopes may form, which steepen when depth increases. Undermining and sudden failure of clay- or peat layers may occur. When located close to structures or embankments, stability may be at stake.

Finally, formulas for the prediction of the equilibrium depth $(1.1-1.3)$ require detailed data on hydrodynamics and geology and perform poorly otherwise. Because these formulas are set up for scour holes in alluvial beds, not all processes are taken into account, so even with proper input conditions, prediction of the equilibrium depth may deviate from reality. Recent research on scour hole formation in non-cohesive sediment under a poorly erodible top layer for example shows that the depth may be overestimated by the formulas by about $20 \%$ (Zuylen 2015).

\subsection{Comparison to scale model tests}

Recently Zuylen and Sloff (2015) performed scale model experiments on scour hole formation in noncohesive sediment under a poorly erodible top layer. Experiments were performed in a $14 \mathrm{~m}$ long flume, with a width and height of $0.4 \mathrm{~m}$. A layer of $0.25 \mathrm{~m}$ of fine sand was covered by two steel plates, representing the poorly erodible layer. The gap between the steel plates was varied between $0.1 \mathrm{~m}$ to $1.0 \mathrm{~m}$. For proper flow conditions, roughness was added to the steel plates. In the gap an asymmetric scour hole developed with a gradual slope on the upstream side and a steep slope on the downstream side, undermining the downstream steel plate. Interestingly, the various scour holes in the Oude Maas show steepest slopes on the predominant upstream side. Note that because the Oude Maas is a tidal river, flow direction turns with every tide.

For a recently formed scour hole in the Oude Maas, the development is shown in Figure 4.4. It shows that the steepest slope and fastest expansion is on the predominant upstream side, suggesting that undermining and failure mostly happens at this side. The opposite behaviour observed in the flume may either be related to wall effects and turbulences in the flume, causing complex 3D flow velocity patterns or by wrong assumptions on the predominant flow direction in the field. In case there is a large asymmetry in the tide or a strong stratification, the highest flow velocities may actually be oriented landward. Because the strongest developments will occur with high flow, this would be in line with the direction in the flume experiments. More research is currently being carried out to clarify the results.

\section{DISCUSSION AND CONCLUSIONS}

In this paper bed topography data, flow velocities and subsurface lithology were analysed to understand the influence of geology on the formation of scour holes. Because of the large number of scour holes and the availability of high quality data, the Rhine-Meuse estuary was used as a case study. In a first step scour holes were identified, classified and their date of origin was estimated. This showed that the majority of scour holes cannot be related to the presence of structures like groynes, bridge piers or local narrowing of the waterway. For these scour holes, the heterogeneity of the subsurface lithology most likely accounts for their existence. 


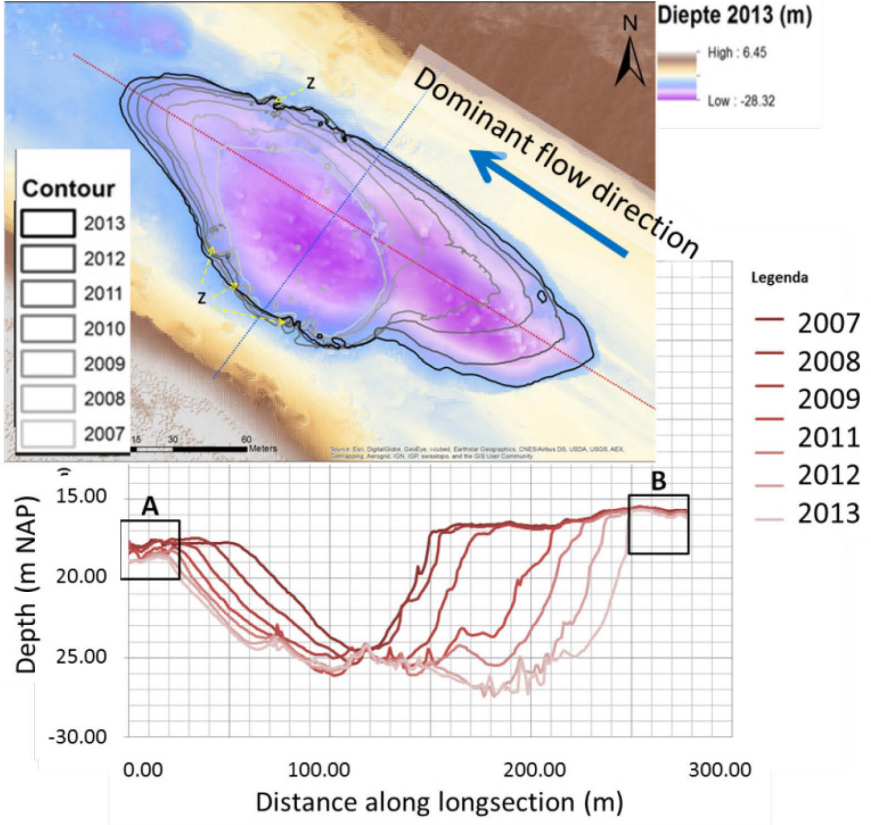

Figure 4.1 Development of a scour hole in the Oude Maas, close to the Beerenplaat. Top figure shows the local bed topography. The contours show the scour area in the subsequent years. The bottom figure shows a longsection of the bed topography.

Analysis of the date of origin revealed how engineering works, like deepening channels, may lead to the formation of new scour holes. In the Dortsche Kil river, four scour holes emerged in the same period that the river was reconstructed. By deepening the river, part of clay and peat layers has probably been removed, uncovering patches of sand, in which scour holes could form.

The detailed analysis highlighted the influence of the geology on the type of growth. When the edges of scour hole are composed of thick layers of poorly erodible material, growth in extent may be limited. This may occur when scour holes have formed in channel belts. When the edges of the scour hole are composed of thin layers of clay or peat, growth in extent will be easier. If a group of scour holes is located close to each other, these may even grow together to form a trench. This will attract flow and enhance its growth. Also the growth in depth is largely influenced by the alternation of poorly erodible and highly erodible layers. Growth in depth may suddenly be accelerated when a highly erodible layer is incised, while it may be drastically slowed down, when the scour hole reaches a clay or peat layer. Predicting the equilibrium depth with formulas is therefore challenging. This would not only require detailed information on the hydrodynamics, but also on the geology. As these formulas are not derived for mixed stratigraphy, certain processes are not accounted for, so even with detailed information, predictions may be off. For better prediction both detailed knowledge and adjustments of the formulas is therefore needed.
In conclusion we can state that a heterogeneous subsoil stratigraphy largely determines the formation of scour holes and their further growth. In combination with anthropogenic influences, the risk of new scour hole formation increases. This has important consequences for engineering of river deltas. Because deltas are commonly densely populated it is common to normalize and deepen the rivers. By normalizing them, erosion will occur. In river beds composed of layers with different erodibility, large scour holes will form in the sandy parts. Deepening channels by dredging may also lead to the formation of new scour holes, as protecting clay or peat layers may locally be removed, exposing sandy parts in which deep scour holes may form. Engineering of river deltas, should consequently be carried out with caution, as most river deltas have a heterogeneous stratigraphy and uncovering or incising sand patches will cause sudden scour hole development. The poor erodibility of the clay or peat layers may hereby limit the growth in extent, while growth in depth may continue, leading to the formation of very steep edges. This may ultimately result in sudden undermining and failure of the apparently stable edges. When located nearly dikes, this poses a potential threat to flood safety.

\section{OUTLOOK}

Recently all scour holes in the area $(\sim 100)$ are analysed on their recent development in depth and extent. Further analysis of these data will be carried out to enhance our understanding of the timeevolution of scour holes in heterogeneous subsurface lithology. Detailed formation processes will be studied by numerical simulations with a code which properly incorporates the detailed hydrodynamic and morphodynamics (Kim et al. 2014; Kim, Nabi, and Shimizu 2014; Nabi et al. 2013), possibly combined with new field measurements on the hydrodynamics in scour holes.

For maintenance purposes, it is important to quickly and unambiguously determine the risks. For this the bed topography and its trend in depth were compared to a theoretical plane. When the river bed drops below this plane, a potential risk for the stability of structures and dikes or insufficient coverage on cables and pipelines is identified. In the future the definition of the level and slopes of the theoretical plane will be optimized based on desired stability criteria for maintenance from the water authority and the newest knowledge on stability criteria for riverbanks and dikes (VTV 2006). 


\section{ACKNOWLEDGEMENTS}

This work was funded by Rijkswaterstaat and by the applied research program of Deltares.

\section{REFERENCES}

Berendsen, H.J.A., and E Stouthamer. 2001. Palaeogeographic Development of the Rhine-Meuse Delta. Assen: Van Gorcum.

Cohen, K.M., E Stouthamer, H.J. Pierik, and A.H. Geurts. 2012. "Digital Basemap for Delta Evolution and Palaeogeography." Dept. Physical Geography.

Hijma, M.P. 2009. "From River Valley to Estuary. The EarlyMid Holocene Transgression of the Rhine-Meuse Valley, The Netherlands." PhD-thesis, Utrecht: KNAG/Faculty of Geographical Sciences, Utrecht University.

Hoffmans, G.J.C.M. 2012. The Influence of Turbulence on Soil Erosion. The Netherlands: Eburon.

Hoffmans, G.J.C.M., and H.J. Verheij. 1997. Scour Manual. Rotterdam: A.A.Balkema.

Huismans, Y, T.S.D. O’Mahony, G. van Velzen, and G.J.C.M Hoffmans. 2015. "Analyse Ontgrondingskuilen RijnMaasmonding." Definitief 1208925-000-ZWS-0022. Advies Beheer Rivierbodem RMM. Deltares.

Huismans, Y., and O.J.M. van Duin. 2016. "Advies Beheer Rivierbodem van de Rijn-Maasmonding." 1208925-000ZWS-0040. Advies Beheer Rivierbodem RMM. Deltares.

Kim, H.S., M. Nabi, I Kimura, and Y. Shimizu. 2014. "Computational Modeling of Flow and Morphodynamics through Rigid-Emergent Vegetation.” 84: 64-86. doi:10.1016/j.advwatres.2015.07.020.

Kim, H.S., M. Nabi, and Y. Shimizu. 2014. "Numerical Investigation of Local Scour at Two Adjacent Cylinders." 70: 131-47. doi:10.1016/j.advwatres.2014.04.018.

Nabi, M., H.J. de Vriend, E. Mosselman, C.J. Sloff, and Y. Shimizu. 2013. "Detailed Simulation of Morphodynamics: 3. Ripples and Dunes." 49: 5930-43. doi:10.1002/wrcr.20457.

Ottevanger, W., and C.F. van der Mark. 2016. "Morfodynamische Modellering Rijn-Maasmonding." 1208925-000ZWS-0030. Advies Beheer Rivierbodem RMM. Deltares.

Sloff, C.J., A. van Spijk, E. Stouthamer, and A.S. Sieben. 2013. "Understanding and Managing the Morphology of Branches Incising into Sand-Clay Deposits in the Dutch Rhine Delta." 28: $127-38$.

VTV. 2006. "Voorschrift Toetsen Op Veiligheid Primaire Waterkeringen." Ministerie van Verkeer en Waterstaat.

Wiersma, A.P. 2015. "De Ondergrond van de Boven Merwede, Dordtsche Kil, Nieuwe Maas En Nieuwe Waterweg." 1208925-000-ZWS-0024. Advies Beheer Rivierbodem RMM. Deltares.

Zuylen, J.A. 2015. "Development of Scour in Non-Cohesive Sediment under a Poorly Erodible Top Layer." Master thesis, Delft: TUDelft.

Zuylen, J.A., and C.J. Sloff. 2015. "Development of Scour in Non-Cohesive Sediments under a Poorly Erodible Top Layer." In RCEM 2015. 